\section{To: (Receiving Organization) \\ DISTRIBUTION}

5. Proj./Prog./Dept./Div.:

HANDI 2000

8. Originator Remarks:

KEY WORDS: H2K, BMS, HANDI 2000, PEORLESOFT. GENERAI LEDGER, PROJECT COSTING, BUSINESS SYSTEM IMPLEMENTATION, FINANCE, AS-IS/TO-BE

11. Receiver Remarks:
3. From: (Originating Organization) SYSTEMS FLUOR DANIEL HANFORD 6. Design Authority/Design Agent/Cog. Engr.:

DAWN $\mathbf{E}$. ADAMS
4. Related EOT No::

N $/ \mathrm{A}$

7. Purchase Order No:

N/A

9. Equip./Component No.:

$\mathrm{N} / \mathrm{A}$

10. System/BIdg./Facility:

$\mathrm{N} / \mathrm{A}$

12. Major Assm. Dwg. No.:

$\mathrm{N} / \mathrm{A}$

13. Permit/Permit Application No.:

$\mathrm{N} / \mathrm{A}$

14. Required Response Date:

$\mathrm{N} / \mathrm{A}$

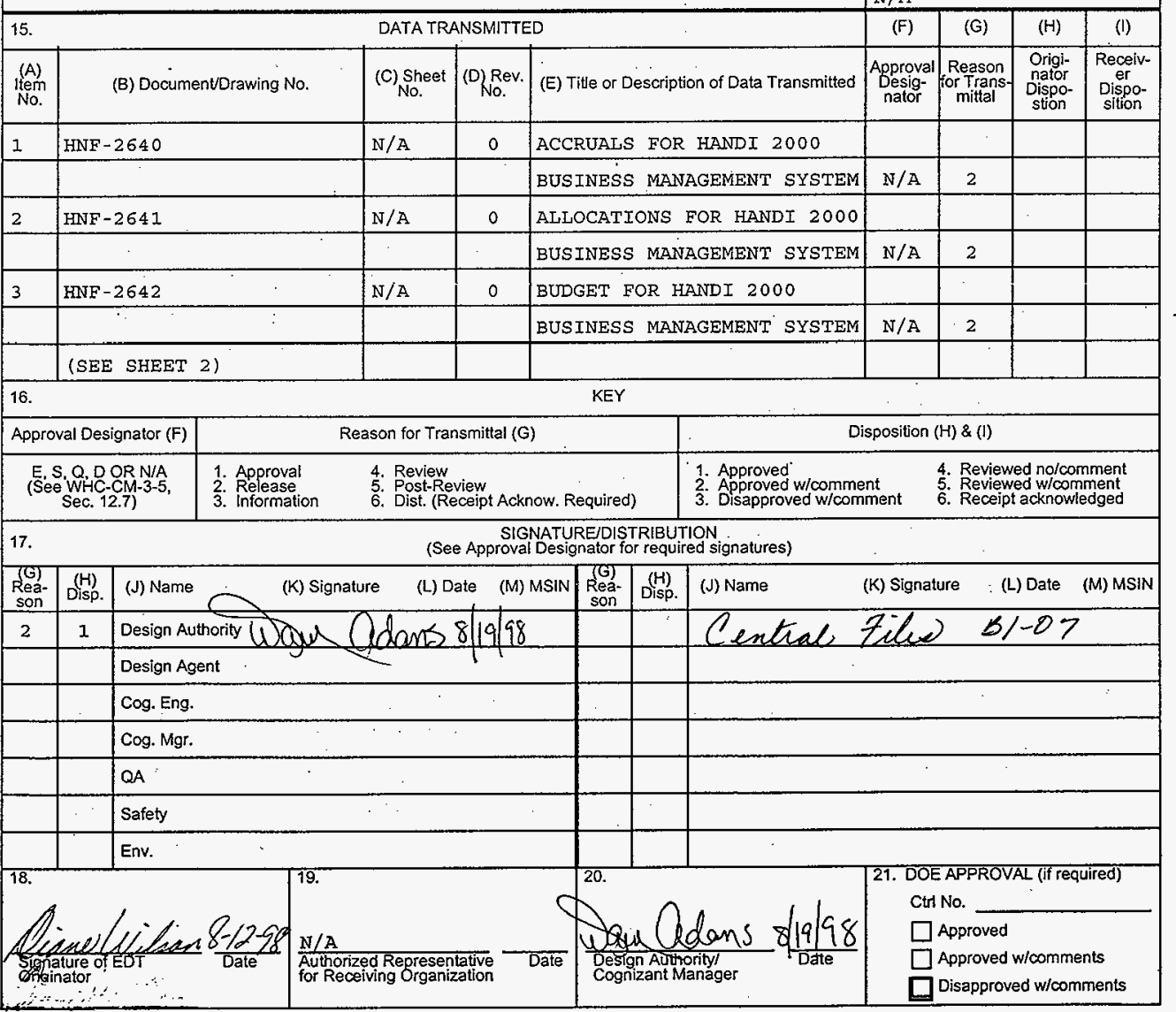




\begin{tabular}{|c|c|c|c|c|c|c|c|c|}
\hline \multirow{2}{*}{\multicolumn{2}{|c|}{\begin{tabular}{|l} 
\\
\\
5. Proj./Prog./Dept.Div.: \\
HANDI 2000
\end{tabular}}} & \multicolumn{7}{|c|}{$\begin{array}{c}\text { ENGINEERING DATA TRANSMITTAL } \\
\text { (CONTINUATION PAGE) }\end{array}$} \\
\hline & & \multicolumn{3}{|c|}{$\begin{array}{l}\text { 6. Cog. Eng. } \\
\text { DAWN E. ADAMS }\end{array}$} & \multicolumn{2}{|l|}{$\begin{array}{l}\text { 1. EDT } \\
625358\end{array}$} & \multicolumn{2}{|c|}{ Page 2 of 4} \\
\hline \multicolumn{2}{|l|}{15.} & \multicolumn{3}{|c|}{ DATA TRANSMITTED } & (F) & (G) & (H) & (l) \\
\hline $\begin{array}{l}\text { (A) } \\
\text { Item } \\
\text { No. }\end{array}$ & (B) Document/Drawing No. & $\begin{array}{l}\text { (C) } \\
\text { Sheet } \\
\text { No. }\end{array}$ & $\begin{array}{l}\text { (D) } \\
\text { Rev. } \\
\text { No. }\end{array}$ & $\begin{array}{l}\text { (E).Title or Description of Data } \\
\text { Transmitted }\end{array}$ & $\begin{array}{l}\text { Approval } \\
\text { Desig- } \\
\text { nator }\end{array}$ & $\begin{array}{l}\text { Reason } \\
\text { for } \\
\text { Trans- } \\
\text { mittal }\end{array}$ & $\begin{array}{l}\text { Origi- } \\
\text { nator } \\
\text { Dispo- } \\
\text { stion }\end{array}$ & $\begin{array}{l}\text { Receiv- } \\
\text { er } \\
\text { Dispo- } \\
\text { sition }\end{array}$ \\
\hline \multirow[t]{3}{*}{4} & HNF -2746 & $\mathrm{~N} / \mathrm{A}$ & 0 & FIT GAP ANALYSIS FOR & $N / A$ & 2 & & \\
\hline & & & & HANDI 2000 BUS INESS & & & & \\
\hline & . & & & MANAGEMENT SYSTEM & & & & \\
\hline \multirow[t]{3}{*}{5} & HNF - 2643 & $\mathrm{~N} / \mathrm{A}$ & 0 & CLOSING PROCEDURE FOR & $N / A$ & 2 & & \\
\hline & & & & HANDI 2000 BUSINESS & & & & \\
\hline & & & & MANAGEMENT SYSTEM & & & & \\
\hline \multirow[t]{3}{*}{6} & HNF - 2644 & $\mathrm{~N} / \mathrm{A}$ & 0 & FIXED ASSETS ACCOUNTING & $N / A$ & 2 & & \\
\hline & & & & FOR HANDI 2000 BUSINESS & & & & \\
\hline & & & & MANAGEMENT SYSTEM & & & & \\
\hline \multirow[t]{3}{*}{7} & $\mathrm{HNF}-2645$ & $\mathrm{~N} / \mathrm{A}$ & 0 & FUNDS CONTROL FOR HANDI & $N / A$ & 2 & & \\
\hline & & & & 2000 BUSINESS MANAGEMENT & & & & \\
\hline & & & & SYSTEM & & & & \\
\hline \multirow[t]{4}{*}{8} & HNF - 2646 & $N / A$ & 0 & GL CHART OF ACCOUNTS & $\mathrm{N} / \mathrm{A}$ & 2 & & \\
\hline & & & & MAINTENANCE FOR HANDI & & & & \\
\hline & & & & 2000 BUSINESS MANAGEMENT & & & & \\
\hline & & & & SYSTEM & & & & \\
\hline \multirow[t]{3}{*}{9} & HNF - 2647 & $\mathrm{~N} / \mathrm{A}$ & 0 & HANFORD BUSINESS & $\mathrm{N} / \mathrm{A}$ & 2 & & \\
\hline & & & & STRUCTURE FOR BUSINESS & & & & \\
\hline & & & & MANAGEMENT SYSTEM & & & & \\
\hline \multirow[t]{3}{*}{10} & HNF - 2648 & $\mathrm{~N} / \mathrm{A}$ & 0 & INVENTORY PROCESSES & $N / A$ & 2 & & \\
\hline & & & & FOR HANDI 2000 BUSINESS & & & & \\
\hline & & & & MANAGEMENT SYSTEM & & & & \\
\hline \multirow[t]{3}{*}{11} & HNF-2649 & $\mathrm{N} / \mathrm{A}$ & 0 & INVOICE/DISCAS FOR HANDI & $N / A$ & 2 & & \\
\hline & & & & 2000 BUSINESS MANAGEMENT & & & & \\
\hline & & & & SYSTEM & & & & \\
\hline \multirow[t]{3}{*}{12} & HNF -2650 & $\mathrm{~N} / \mathrm{A}$ & 0 & LABOR COSTING FOR HANDI & $\mathrm{N} / \mathrm{A}$ & 2 & & \\
\hline & & & & 2000 BUSINESS MANAGGEMENT & & & & \\
\hline & & & & SYSTEM & & & & \\
\hline \multirow[t]{5}{*}{13} & HNF - 2651 & $\mathrm{~N} / \mathrm{A}$ & 0 & PASSPORT-PEOPLESOFT & $\mathrm{N} / \mathrm{A}$ & 2 & & \\
\hline & & & & INTEGRATION FOR HANDI & & & & \\
\hline & $\cdot$ & & & 2000 BUSINESS MANAGEMENT & & & & \\
\hline & & & & SYSTEM & & & & \\
\hline & (CONTINUED ON PG 3) & & & & & & & \\
\hline
\end{tabular}




\section{ENGINEERING DATA TRANSMITTAL}

(CONTINUATION PAGE)

\section{Proj./Prog.JDept.Div.:}

HANDI 2000
6. Cog. Eng.

DAWN E. ADAMS
1. EDT

625358

Page 3 of 4
15.

\section{(A)}

Item

No.

14 HNF - 2652

\begin{tabular}{|l|l|}
\hline & \\
\hline & \\
\hline
\end{tabular}

(B) Document/Drawing No.

\section{5}

HNF -2653

$16 \quad$ HNF -2654

\begin{tabular}{|r}
\hline \\
\hline
\end{tabular}

\begin{tabular}{|l|l}
\hline 17 & HNF -265 \\
\hline
\end{tabular}

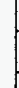

$18 \quad$ HNF -265

$19 \quad$ HNF -2658

$20 \quad$ HNF -2659

\begin{tabular}{l|l}
\hline \\
\hline
\end{tabular}

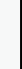

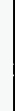

\begin{tabular}{|l|l|l|l|}
\hline & & & \\
\hline 21 & HNF -2661 & N/A & 0 \\
\hline & & & \\
\hline & & & \\
\hline 22 & HNE-2662 & & \\
\hline & & N/A & 0 \\
\hline & & & \\
\hline & (CONTINUED ON PG 4) & & \\
\hline
\end{tabular}

DATA TRANSMITTED

\section{(F)}

Aoproval or Description of Data

Sheet Rev. \begin{tabular}{ll} 
Noel & No. \\
\hline
\end{tabular}

\begin{tabular}{l|l}
\hline N/A & 0 \\
\hline
\end{tabular}

HANDI 2000 BUSINESS

MANAGEMENT SYSTEM

\begin{tabular}{|l|l|l|} 
& & MANAGEMENT SYSTEM \\
\hline N/A & 0 & OTS CASH DISBURSEMENT \\
\hline
\end{tabular}

PROCESS FOR BUSINESS

MANAGEMENT SYSTEM

TRAVEL EXPENSE

REIMBURSEMENT FOR HANDI

2000 BUSINESS MANAGEMENT

SYSTEM

CASH RECEIPTS PROCESS FOR

HANDI 2000 BUSINESS

MANAGEMENT SYSTEM

INSURANCE PAYMENT PROCESS

\begin{tabular}{|l|l} 
N/A & 2 \\
\hline
\end{tabular}

FOR HANDI 2000 BUSINESS

MANAGEMENT SYSTEM

SAVINGS PIAAN PAYMENT

PROCESS FOR HANDI 2000

BUSINESS MANAGEMENT

SYSTEM

\begin{tabular}{ll|l|l} 
WORK PERFORMED BY ENTER- & N/A & 2
\end{tabular}

PRISE COMPANIES (ENCO)

FOR (PHMC) FOR HANDI 2000

BUSINESS MANAGEMENT

SYSTEMS

WORK PERFORMED BY PHMC

FOR OHC-WORK ORDER FOR

HANDI 2000 BUSINESS

MANAGEMENT SYSTEM

\begin{tabular}{ll|l|l} 
WORK PERFORMED BY OHC FOR & N/A & 2
\end{tabular}

PHMC-WORK ORDER PROCESS

FOR HANDI 2000 BUSINESS

MANAGEMENT SYSTEM

\begin{tabular}{|c|c|c|}
\hline$(\mathrm{G})$ & $(\mathrm{H})$ & $(\mathbf{I})$ \\
\hline Reason & Origi- & Receiv- \\
for & nator & er \\
Trans- & Dispo- & Dispo- \\
mittal & stion & sition \\
\hline
\end{tabular}




\begin{tabular}{|c|c|c|c|c|c|c|c|c|}
\hline \multicolumn{9}{|c|}{$\begin{array}{c}\text { ENGINEERING DATA TRANSMITTAL } \\
\text { (CONTINUATION PAGE) }\end{array}$} \\
\hline \multicolumn{2}{|c|}{$\begin{array}{l}\text { 5. Proj.lProg.JDept.Div.: } \\
\text { HANDI } 2000\end{array}$} & \multicolumn{3}{|c|}{$\begin{array}{l}\text { 6. Cog. Eng. } \\
\text { DA.WN E. ADAMS }\end{array}$} & \multicolumn{2}{|l|}{625358} & \multicolumn{2}{|c|}{ Page 4 of 4} \\
\hline \multicolumn{2}{|l|}{15.} & \multicolumn{3}{|c|}{ DATA TRANSMITTED } & (F) & (G) & (H) & (1) \\
\hline $\begin{array}{l}\text { (A) } \\
\text { Item } \\
\text { No. }\end{array}$ & (B) DocumentDrawing No. & $\begin{array}{l}\text { (C) } \\
\text { Sheet } \\
\text { No. }\end{array}$ & $\begin{array}{l}\text { (D) } \\
\text { Rev. } \\
\text { No. }\end{array}$ & $\begin{array}{l}\text { (E) Title or Description of Data } \\
\text { Transmitted }\end{array}$ & $\begin{array}{l}\text { Approval } \\
\text { Desig- } \\
\text { nator }\end{array}$ & $\begin{array}{l}\text { Reason } \\
\text { for } \\
\text { Trans- } \\
\text { mittal } \\
\end{array}$ & $\begin{array}{c}\text { Origi- } \\
\text { nator } \\
\text { Dispo- } \\
\text { stion }\end{array}$ & $\begin{array}{l}\text { Receiv- } \\
\text { er } \\
\text { Dispo- } \\
\text { sition }\end{array}$ \\
\hline \multirow[t]{4}{*}{23} & HNF -2663 & $\mathrm{~N} / \mathrm{A}$ & 0 & WALK-IN WORK FOR OTHER & $\mathrm{N} / \mathrm{A}$ & 2 & & \\
\hline & & & & HANFORD CONTRACTORS FOR & & & & \\
\hline & . & & & HANDI 2000 BUSINESS & & & & \\
\hline & & & & MANAGEMENT SYSTEM & & & & \\
\hline \multirow[t]{4}{*}{24} & HNF -2664 & $\mathrm{~N} / \mathrm{A}$ & 0 & DOE HANFORD REQUEST FOR & & & & \\
\hline & & & & SERVICES FOR HANDI 2000 & & & & \\
\hline & & & & BUSINESS MANAGEMENT & & & & \\
\hline & & & & SYSTEM & & & & \\
\hline & & & & & & & & \\
\hline & & . & & & & & & \\
\hline & & & & & & & & \\
\hline & & & & & & & & \\
\hline & & & & & & & & \\
\hline & & & & & & & & \\
\hline & & & & & & & & \\
\hline & & & & & & & & \\
\hline & & & & & & & & \\
\hline & & & & & & & & \\
\hline & & & & & & & & \\
\hline & & & & & & & & \\
\hline & & & & & & & & \\
\hline & & & & & & & & \\
\hline & & & & & & & & \\
\hline & . & & & & & & & \\
\hline & & & & & & & & \\
\hline & & & & & & & & \\
\hline & & & & & & & & \\
\hline & & & & & & & & \\
\hline & & & & & & & & \\
\hline & & & & . & & . & & \\
\hline & & & & & & & & \\
\hline & & & & & & & & \\
\hline & & & & & & & & \\
\hline
\end{tabular}




\title{
UNIT BILLED SERVICES FOR HANDI 2000 BUSINESS MANAGEMENT SYSTEM
}

\author{
Diane wilson, Fluor Daniel Hanford Co. \\ MSN G1-22 \\ Richland, WA 99352 \\ U.S. Department of Energy Contract DE-AC06-96RL13200

$\begin{array}{cll}\text { EDT/ECN: } 625358 & \text { UC: } 900 \\ \text { Org Code: } & \text { FK260000 } & \text { Charge Code: YBPME } \\ \text { B\&R Code: } & \begin{array}{c}\text { EWF00100 } \\ 7070100\end{array} & \text { Total Pages: }\end{array}$

Key Words: HUB, FLOW CHART, As-Is/To-Be

Abstract: Unit billed services are thos services provided internally by project to other projects, except for thos services furnished by Lockheed Martin Services, Inc., an Engerprise Company. These services are billed when the actual work is performed, based on a published rate for the service. Examples of this would be crane \& rigging, duplicating, or lab analysis. The providers of these services collect their costs in a "pool". The poolis then liquidated by the billings, which is the ...

TRADEMARK DISCLAIMER. Reference herein to any specific commercial product, process, or service by trade name, trademark, manufacturer, or otherwise, does not necessarily constitute or imply its endorsement, recommendation, or favoring by the United States Government or any agency thereof or its contractors or subcontractors.

Printed in the United States of America. To obtain copies of this document, contact: Document Control Services, P.O. Box 950, Mailstop H6-08, Richland WA 99352, Phone (509) 372-2420; Fax (509) 376-4989.

Excel is a trademark of Microsoft Corporation Peoplesoft is a trademark of Indus corp.
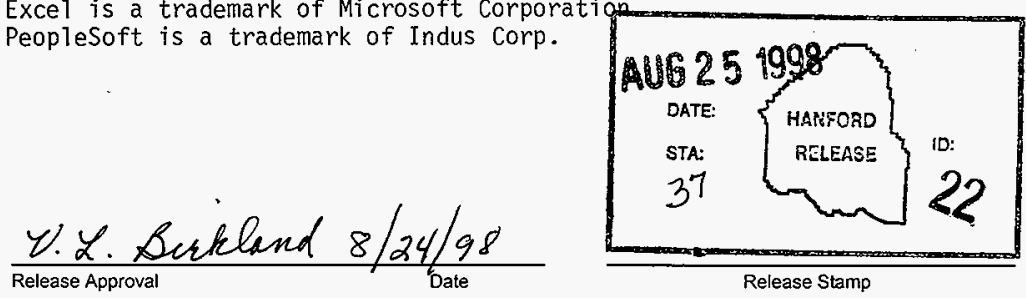


\section{Memorandum}

To:
D.E. Adams
G1-21
M.J. Byrd
H2- 08 ,
A.A. Carter
H2-19,
C.R. Hopkins G1-57,

K.B. Adamsons H2-19

R.C. Corless H2-19,

J.A. Caldwell G1-22,

R.J. McFadzean H2-19

From: P. C. Felts

Date: April 17, 1998

Re: PeopleSoft General Ledger / Project Costing - Business System Implementation Sessions Final Documentation

\section{HANDI 2000 - Finance}

Attached for your information is the complete set of documentation of the work flow analysis from the Business System Implementation (BSI) Sessions.

One of the goals of finalizing documentation from the BSI Sessions is to use the documents as a communication tool.

Other goals of the BSI sessions were to validate the As-Is process, and describe the vision of the To-Be process that fit the baseline software processes. In the future, this documentation will be accessible electronically via a read-only shared area.

I thank you and your staff for your support during this information gathering and envisioning stage of the new system implementation project

If you have any questions, I can be reached on 376-0367 or via email.

Attachment 
Date:

$4 / 17 / 98$

Documentation: Finance Business System Implementation (BSI) Sessions

Processes Included:

- Accrual

- Allocations

- Budget

- Fit-Gap Analysis

- Closing Procedure

- Fixed Assets Accounting

- Funds Control

- General Ledger Account Maintenance

- Hanford Business Structure

- Inventory Processes

- Invoice/DISCAS

- Labor Costing

- Passport-PeopleSoft Integration

- Unit Billed Service

- Travel \& Treasury:

- OTS Cash Disbursement Process

- Travel Expense Reimbursement

- Cash Receipt Process

- Savings, Pensions, \& Insurance:

- Insurance Payment Process

- Pension Payment Process

- Savings Plan Payment Process

_ Other Hanford Contractors:

- Worked Performed by Enco's for PHMC

- Worked Performed by Enco's for OHC

- Worked Performed by PHMC for OHC - Work Order

- Worked Performed by OHC for PHMC - Work Order Process

- Worked Performed by PHMC for OHC - Walk In

- Worked Performed by PHMC for DOE-Richland using the Request for Service Process

FDH Project Lead: Name

Signature

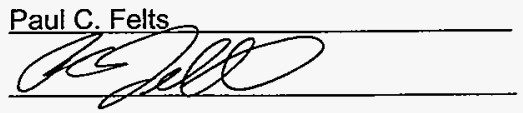




\section{Unit Billed Services}

\section{Overview}

Unit billed services are those services provided internally by projects to other projects, except for those services furnished by Lockheed Martin Services, Inc. (LMSI), an Enterprise Company (ENCO). These services are billed when the actual work is performed, based on a published rate for the service.

Examples of this would be crane \& rigging, duplicating, or lab analysis. The providers of these services collect their costs in a "pool". The pool is then liquidated by the billings, which is the results of an allocation/cost transfer of the pool based on usage by Projects. Currently the billings can only be seen in the General Ledger.

\section{Assumptions}

- HUB will stay as a feeder system to capture and transfer information to PeopleSoft to generate internal billing entries. PeopleSoft will then build the offsetting entries to liquidate the pools.

A separate code of account will be used to show billing information and the offset to the pools.

$\square$ Resource type for unit billed services will be ODC - Other Direct Costs.

ㅁ. Resource category will identify the specific type of service.

\section{As is Process}

D Detailed Ledger Entries (DLE) account for approximately $30 \%$ of all service billings. The DLE's are EXCEL uploads, automated or manually entered. Hanford Unit Billing (HUB) accounts for approximately $60 \%$ of all service billings. There are currently 6 other systems that feed HUB. The remaining come from TRI (Training), Standards Lab (SLIC), or Vehicle Fleet Management (VFM).

$\square$ HUB prices entries that are input to it. It also accepts priced entries from some systems.

$\square$ The Financial Data System (FDS) builds all offsetting entries. See flow below. 


\section{Hanford Unit Billing (HUB)}

Records from HUB are summarized on the following fields: Co-ID, Org, Charge code, Ticket \#, and cost element. Records also include support from code, hours/quantity, amount, work order \# and system code (HUB).

Within FDS edits and pricing processes the following records are built:

\section{General Ledger}

8132 - Project

Debit

Debit

\section{Expense Master}

(Project Costing)

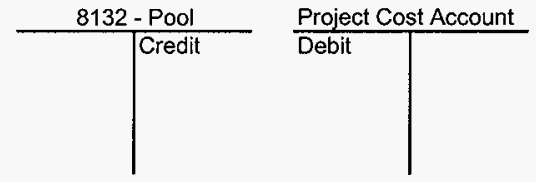

Offsetting entries are built based on cost element and special activity table lookup (flow chart to follow) 


\section{Unit Billed Services}

Flow and records built by FDS

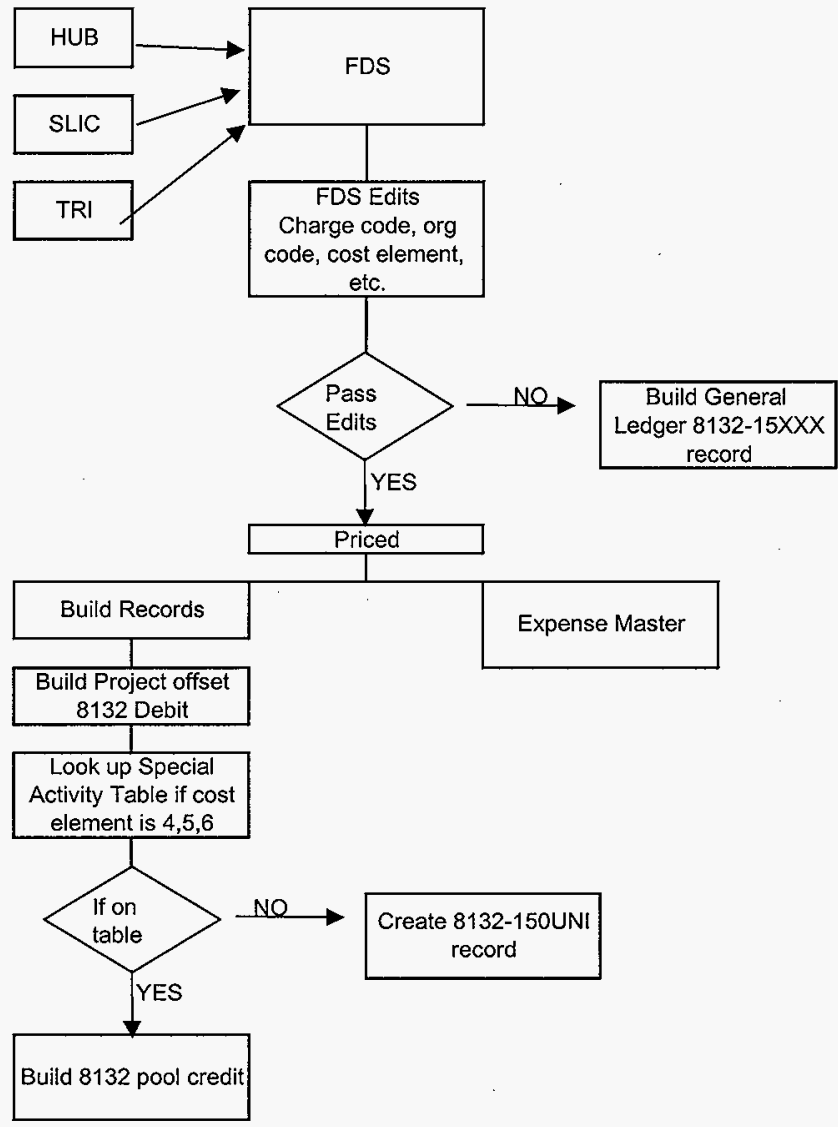


A resource type will be assigned to records sent to PeopleSoft that will identify the originating HUB transaction.

$\square$ Billings will show on projects against the cost of the service provider.

ㄱ P3 may need some modification to accommodate the new resource types and categories.

Feeder systems will have to add functionality to capture Project Id and Code of Account.

\section{Issues \& Action Items}

Issues

See issues log.

\section{To Be}

- Hub will continue to send information to PeopleSoft. Projects will then create the offsetting General Ledger entry and pass it to the GL as a balanced entry.

$\square$ A cost transfer/allocation process will be run to liquidate the pools and bill the projects that utilized their services. This process will originate in the PeopleSoft Projects module and be sent to the General Ledger, so that the subsidiary ledger is in synch with the General Ledger.

- All Hub transactions will be sent to an Other Direct Cost account, with the offsetting entry sent to a holding account to be liquidated via the cost transfer/allocation process.

$\square$ The basis and pool for all cost transfers, usage, and allocations will be the PeopleSoft Projects module. 